\title{
Prophylactic effects of Clausena excavata Burum. $f$. leaf extract in ethanol-induced gastric ulcers
}

This article was published in the following Dove Press journal:

Drug Design, Development and Therapy

15 June 2016

Number of times this article has been viewed

\author{
Shaymaa Fadhel Abbas \\ Albaayit ${ }^{1,2}$ \\ Yusuf $\mathrm{Abba}^{3}$ \\ Rasedee Abdullah ${ }^{4}$ \\ Noorlidah Abdullah' \\ 'Faculty of Science, Institute of \\ Biological Sciences, University of \\ Malaya, Kuala Lumpur, Malaysia; \\ ${ }^{2}$ Department of Biology, College of \\ Science, University of Baghdad, \\ Baghdad, Iraq; ${ }^{3}$ Department \\ of Veterinary Pathology and \\ Microbiology, ${ }^{4}$ Department of \\ Veterinary Laboratory Diagnosis, \\ Faculty of Veterinary Medicine, \\ Universiti Putra Malaysia, Serdang, \\ Selangor, Malaysia
}

\begin{abstract}
Clausena excavata is a natural herb with both antioxidant and anti-inflammatory properties. It has been used for decades in folkloric practice for the amelioration of various ailments. In this study, the gastroprotective activity of methanolic extract of $C$. excavata leaves (MECE) was determined in the Sprague Dawley rat ethanol-induced gastric ulcer model. Rats were pretreated with a single dose of vehicle (5\% Tween 20$), 20 \mathrm{mg} / \mathrm{mL}$ omeprazole, 400 and $200 \mathrm{mg} / \mathrm{mL}$ of MECE dissolved in 5\% Tween 20. Ulcer was induced with $5 \mathrm{~mL} / \mathrm{kg}$ of ethanol and stomach tissue was obtained after 1 hour. Histological examination was done on hematoxylin and eosin, periodic acid-Schiff, and immunochemically stained gastric mucosal tissues. Prostaglandin E2, superoxide dismutase, catalase, glutathione peroxidase, and lipid peroxidation levels of the gastric tissue homogenates were also determined. Significantly $(P<0.05)$ smaller ulcer areas, less intense edema, and fewer leukocytes' infiltration were observed in MECE- and omeprazole-treated than in untreated gastric mucosa with ulcer. The gastric $\mathrm{pH}$, mucus production, superoxide dismutase, catalase, and glutathione peroxidase contents increased, while the lipid peroxidation content decreased as a result of MECE treatment. Bcl-2-associated X protein was underexpressed, while heat shock protein 70 and transforming growth factor-beta protein were overexpressed in the ulcerated gastric mucosa tissues treated with omeprazole and MECE. Similarly, there was a reduction in the levels of tumor necrotic factor-alpha and interleukin-6, while the level of interleukin-10 was increased. This study showed that the gastroprotective effect of MECE is achieved through inhibition of gastric juice secretion and ulcer lesion development, stimulation of mucus secretion, elevation of gastric $\mathrm{pH}$, reduction of reactive oxygen species production, inhibition of apoptosis in the gastric mucosa, and modulation of inflammatory cytokines.
\end{abstract}

Keywords: Rutaceae, antiulcer, antioxidant enzymes, histopathology, immunohistochemical proteins, cytokines

\section{Introduction}

Peptic ulcer disease (PUD), a protracted and multifactorial disease, is characterized by the presence of ulcerated lesions in the gastric or duodenal mucosa. PUD occurs in approximately $20 \%$ of the world population. ${ }^{1}$ Development and progression of PUD is governed by the acidity of the stomach's gastric juice. Thus, modulation of the stomach acidity is fundamental to the prevention and healing of gastric ulcers. ${ }^{2}$ Although several antiulcer medications such as $\mathrm{H} 2$ receptor antagonists (ranitidine, famotidine), antacid, and proton-pump inhibitors (omeprazole) are readily available for the treatment of ulcers, these therapeutic agents have side effects that include impaired calcium, iron, magnesium, and vitamin B12 absorption in the intestine. Hence, there is a great need to develop more efficacious drugs for the treatment of the disease. ${ }^{3}$ 
Ethanol has been shown to induce oxidative stress that manifests as an increase in malondialdehyde and decrease in catalase (CAT) and glutathione activities. Oral application of ethanol causes gastric mucosal damage with hemorrhage and ulceration. This deleterious effect of ethanol is often used in laboratory animals to develop gastric ulcer models. ${ }^{4-6}$

The antiulcerogenic effects of many natural compounds have been attributed to their antioxidant properties and regulation of oxidative stress enzymes and protein expression. The leaves of Clausena excavata (Rutaceae) are traditionally used in the treatment of malaria, stomachache, abdominal pain, cold, headache, pulmonary tuberculosis, wound, dysentery, snakebite, poisoning, and diarrhea.${ }^{5,6}$ C. excavata has also been shown to have antioxidant, immune-modulatory, analgesic, anti-inflammatory, antiviral, anticancer, antioxidant, antimycobacterial, and antifungal properties. ${ }^{7-11}$ However, there is no report on the antiulcer effect of the plant. Thus, this study was undertaken to investigate the prophylactic potential of methanolic extract of C. excavata leaf extract in a rat ulcer model.

\section{Materials and methods}

\section{Preparation of $C$. excavata extract}

The $C$. excavata plant was obtained from Pendang, Kedah $\left(5^{\circ} 59^{\prime} \mathrm{N}, 100^{\circ} 28^{\prime} \mathrm{E}\right)$, Malaysia, and identified and authenticated by Dr Shamsul Khamis, a resident botanist at the Biodiversity Unit, Institute of Bioscience, Universiti Putra Malaysia, Malaysia. Plant samples are naturally grown in the fields and are not classified as endangered species. Therefore, no specific permission was required for sample collection. Fresh C. excavata leaves were cleaned, shade-dried for 2 weeks, powdered, and soaked in methanol for 3 days. The solvent was removed by rotary evaporation and the extract stored at $4^{\circ} \mathrm{C}$. Methanolic extract of C. excavata (MECE) leaves was chosen for the study because it was shown to have significant antioxidant activities. ${ }^{8}$

\section{In vitro assay}

\section{Cell maintenance}

J774A.1 macrophage cell line (American Type Culture Collection [ATCC], Manassas, VA, USA) was cultured in Dulbecco's Modified Eagle's Medium, supplemented with $10 \%$ fetal bovine serum, and incubated at $37^{\circ} \mathrm{C}$ in a $5 \%$ $\mathrm{CO}_{2}$ humidified incubator. Cells that reached $80 \%$ confluence were detached from the culture flasks by addition of trypsin-ethylenediaminetetraacetic acid (EDTA), centrifuged at 2,000 $\mathrm{g}$ for 10 minutes, stained with trypan blue, and counted in a Neubauer chamber.
3-(4,5-Dimethylthiazol-2-yl)-2,5-diphenyltetrazolium bromide assay

Stock MECE was dissolved in $0.1 \%$ dimethyl sulfoxide. The J774A.1 cells were seeded at a density of $5 \times 10^{4}$ cells/ well/100 $\mu \mathrm{L}$ in a 96-well plate, treated with $25,50,100$, 200 , and $400 \mu \mathrm{g} / \mathrm{mL}$ MECE in Dulbecco's Modified Eagle's Medium with $2 \%$ fetal bovine serum, and incubated at $37^{\circ} \mathrm{C}$ under $5 \% \mathrm{CO}_{2}$ for 24 hours. Cell proliferation was determined by 3-(4,5-dimethylthiazol-2-yl)-2,5-diphenyltetrazolium bromide assay. Twenty microliters of 3-(4,5-dimethylthiazol2-yl)-2,5-diphenyltetrazolium bromide reagent $(5 \mathrm{mg} / \mathrm{mL})$ was added to each well and the plate incubated for 3 hours. The purple formazan formed was solubilized with $100 \mu \mathrm{L}$ dimethyl sulfoxide. The plate was swirled gently to mix and kept in the dark at room temperature for approximately 20 minutes. The absorbance was determined using a microplate reader (Tecan, Grödig, Austria) at $570 \mathrm{~nm}$ with reference at $630 \mathrm{~nm}$. Each concentration was tested in triplicate.

\section{Animals}

Fifty-four disease-free, adult male Sprague Dawley rats (weighing 220-240 g) aged 6 weeks were purchased from the Animal Resource Centre, Faculty of Veterinary Medicine, Universiti Putra Malaysia. The rats were housed in groups of three per cage and allowed to acclimatize, with free access to commercial feed and water for 1 week prior to experimentation. The experiment was conducted under a constant ambient temperature of $22^{\circ} \mathrm{C}$ and 12 -hour light/ dark cycle.

\section{Ethics statement}

This study was conducted in strict compliance with the guidelines set by the Institutional Animal Care and Use Committee (IACUC), University of Malaya. All experimental studies conducted were approved by the institutional IACUC with approval no: ISN/22/007/2013/1111/SFA. The animals were handled and treated humanely, according to the criteria outlined in the Guide for the Care and Use of Laboratory Animals. ${ }^{12}$

\section{Selection of dose of extract}

Determination of acute toxicity of C. excavata was done in our earlier study as per the guidelines of the Organization for Economic Cooperation and Development using MECE at doses of 2,000 and $5,000 \mathrm{mg} / \mathrm{kg}$ body weight in both male and female rats. ${ }^{8}$ The rats were observed for 48 hours for development of signs of pain, distress, or mortality and euthanized under $\mathrm{CO}_{2}$ at day 14 posttreatment. Based on that 
study, we adopted the doses of 200 and $400 \mathrm{mg} / \mathrm{kg}$ body weight for use in this study.

\section{Antisecretory effect}

The antisecretory effect of MECE was determined in rats according to the method of Shay ${ }^{13}$ with slight modifications. Briefly, 24 rats, assigned to four equal groups, were fasted for 24 hours with free access to water. The rats were then pretreated once by oral gavage as follows:

Group 1: 5\% Tween $20 \mathrm{v} / \mathrm{v}$ (negative control)

Group 2: $20 \mathrm{mg} / \mathrm{kg}$ body weight omeprazole (positive control)

Group 3: $200 \mathrm{mg} / \mathrm{kg}$ body weight MECE dissolved in 5\% Tween $20 \mathrm{v} / \mathrm{v}$

Group 4: $400 \mathrm{mg} / \mathrm{kg}$ body weight MECE dissolved in 5\% Tween $20 \mathrm{v} / \mathrm{v}$.

After 1 hour, the rats were anesthetized through intramuscular route with a combination of ketamine $(50 \mathrm{mg} / \mathrm{kg})$ and xylazine $(5 \mathrm{mg} / \mathrm{kg})$. The abdomen was opened by making a small midline incision below the xiphoid process. The pyloric portion of the stomach was slightly lifted and ligated, avoiding traction to the pylorus or damage to blood vessels. The stomach was then carefully put back into the abdominal cavity and the abdominal wall was sutured. After 4 hours, all rats were euthanized under $\mathrm{CO}_{2}$, their stomachs immediately removed, and the volume and $\mathrm{pH}$ of gastric content determined. Total acidity of the gastric content was determined by titrating with $0.01 \mathrm{~N}$ sodium hydroxide $(\mathrm{NaOH})$ solution using phenolphthalein as an indicator, and calculated using the formula: total acidity $(\mathrm{mEq} / \mathrm{L})=$ volume of $\mathrm{NaOH}$ solution $\times 0.01 \times 36.45 \times 1,000 .^{13,14}$

\section{Rat gastric ulcer model}

Thirty male rats were randomly divided into five groups of six rats each in wire-bottomed cages, fasted for 24 hours, and deprived of water for 2 hours. The rats were orally pretreated as follows:

Group 1: vehicle (5\% Tween $20 \% \mathrm{v} / \mathrm{v}, 5 \mathrm{~mL} / \mathrm{kg}$ body weight) (normal control)

Group 2: absolute ethanol ( $5 \mathrm{~mL} / \mathrm{kg}$ body weight) (ulcer control)

Group 3: $20 \mathrm{mg} / \mathrm{kg}$ body weight omeprazole in 5\% Tween $20 \mathrm{v} / \mathrm{v}$ (positive control)

Group 4: $200 \mathrm{mg} / \mathrm{kg}$ body weight of MECE dissolved in $5 \%$ Tween $20 \mathrm{v} / \mathrm{v}$

Group 5: $400 \mathrm{mg} / \mathrm{kg}$ body weight of MECE dissolved in $5 \%$ Tween $20 \mathrm{v} / \mathrm{v}$.
One hour after pretreatment, all rats, except the normal controls, were orally gavaged with $5 \mathrm{~mL} / \mathrm{kg}$ body weight absolute ethanol, anesthetized by intramuscular route with a combination of ketamine $(50 \mathrm{mg} / \mathrm{kg})$ and xylazine $(5 \mathrm{mg} / \mathrm{kg})$, and their stomachs immediately removed..$^{15,16}$

\section{Evaluation of gross lesions on the gastric mucosa}

Gastric ulcers appeared as elongated bands of hemorrhagic lesions on the stomach mucosal surface. The ulcer area was determined by counting $2 \times 2 \mathrm{~mm}^{2}$ areas under a gridfitted dissecting microscope at $\times 1.8$ magnification. The total lesion area for each stomach was calculated from the following formula: ulcer area $\left(\mathrm{mm}^{2}\right)=\left(\right.$ sum of $2 \times 2 \mathrm{~mm}^{2}$ squares counted) $\times 4 \times 1.8$. The inhibition percentage was then calculated as described earlier. ${ }^{17,18}$

\section{Gastric mucus content and juice acidity}

The gastric mucosa was gently scrapped using a glass slide to obtain mucus and gastric mucosal tissue, which were weighed. Gastric juice was collected and centrifuged at $4,000 \times g$, at room temperature for 10 minutes. The acidity of the supernatant was determined using a digital $\mathrm{pH}$ meter.

\section{Histopathology and lesion evaluation}

A small piece of the ulcerated gastric mucosal tissue from each group was fixed with $10 \%$ buffered formalin solution and dehydrated with alcohol and finally embedded in paraffin wax. Tissue sections of $5 \mu \mathrm{m}$ were cut and stained with hematoxylin and eosin for light microscopic examination. ${ }^{19}$ Lesions such as hemorrhage, submucosal edema, epithelial erosion, and inflammatory cell infiltrates were determined in one unit of microscopic focus field, equivalent to $2 \times 2 \mathrm{~mm}^{2}$ area of the tissue having a lesion. Tissue sections were also stained with periodic acid-Schiff stain for evaluation of mucus production. ${ }^{20}$

\section{Immunohistochemical staining for Bax, heat shock protein 70 , and transforming growth factor-beta}

Tissue sections were deparaffinized for 15 minutes at $58^{\circ} \mathrm{C}$ before immersing in decreasing concentrations of $100 \%$, $80 \%, 70 \%$, and $50 \%$ alcohol for 5 minutes each, followed by hydration in phosphate-buffered saline (PBS) twice for 5 minutes. The sections were then heated in $10 \mathrm{mM}$ tris buffer ( $\mathrm{pH}$ 9.0) for 15 minutes in order to retrieve the antigens. The slides were allowed to cool to room temperature and endogenous peroxidase was blocked by incubating the sections in $3 \% \mathrm{H}_{2} \mathrm{O}_{2}$ for 10 minutes at room temperature. The slides were then washed twice with PBS and incubated 
with rabbit primary anti-heat shock protein (anti-HSP70), anti-Bcl-2-associated X protein (anti-Bax), or transforming growth factor-beta (TGF- $\beta$ ) antibodies (Abcam, Cambridge, UK) at dilutions of 1:500, 1:200, and 1:800, respectively. The slides were incubated in a humidified dark chamber at room temperature for 30 minutes before immersion in $0.1 \%$ Tween 20 dissolved in PBS twice for 5 minutes each. Horseradish peroxidase-conjugated secondary antibodies (Envision Systems, South Melbourne, Australia) were added to the sections and the slides were incubated at room temperature for 30 minutes. Furthermore, the sections were incubated with a substrate, 3,3'-diaminobenzidine tetrahydrochloride (Dako, Carpintaria, CA, USA), allowed to stand at room temperature for 5 minutes, counterstained with Harris hematoxylin, dehydrated with $50 \%, 70 \%, 80 \%$, and 100\% alcohol, and finally cleared in xylene. Air-dried sections were mounted with DPX mountant for light microscopic examination.

\section{Evaluation of immunopositive gastric tissue sections}

Brown-colored cells, signifying positive staining, were selected and estimated as a proportion of the total focal slide area using the ImageJ software (National Institutes of Health, Bethesda, MD, USA) (http://imagej.nih.gov/ij/). Six microscopic focal fields at $\times 200$ magnification were captured from each slide and used for the ImageJ analysis. Briefly, images were opened with the ImageJ software using the file menu and RGB stack was created from the image menu. An image montage was created from the image stack and the best montage was used to adjust the threshold in order to select the most precise stained areas. Measurement parameters such as area, mean, standard deviation, area fraction, limit to threshold, and display label were selected and measurement values were obtained. Each replicate from the same group was evaluated and mean \pm standard error of the mean of the stained areas $\left(\mu \mathrm{m}^{2}\right)$ determined. ${ }^{21}$

\section{Antioxidant activity}

\section{Superoxide dismutase assay}

Gastric mucosal tissues in $20 \mathrm{mM}$ 4-(2-hydroxyethyl)-1-piperazineethanesulfonic acid (HEPES) buffer ( $\mathrm{pH} 7.2$ ), containing $1 \mathrm{mM}$ EDTA, $210 \mathrm{mM}$ mannitol, and $70 \mathrm{mM}$ sucrose, were homogenized on ice and centrifuged at $1,500 \times g$, at $4^{\circ} \mathrm{C}$ for 10 minutes. The supernatant was harvested and used for the determination of superoxide dismutase (SOD) activity using the Cayman SOD assay kit (Cayman, Ann Arbor, MI, USA).

\section{Catalase activity assay}

Gastric mucosal tissues in cold $50 \mathrm{mM}$ potassium phosphate buffer ( $\mathrm{pH}$ 7.0), containing 1 mM EDTA, were homogenized on ice and centrifuged at $10,000 \times g$, at $4^{\circ} \mathrm{C}$ for 15 minutes. The supernatant was harvested and used for the determination of CAT activity using the Cayman CAT assay kit (Cayman).

\section{Glutathione peroxidase assay}

Gastric mucosal tissues in $50 \mathrm{mM}$ Tris- $\mathrm{HCl}$ ( $\mathrm{pH} 7.5)$, containing $5 \mathrm{mM}$ EDTA and $1 \mathrm{mM}$ dithiothreitol, were homogenized and centrifuged at $10,000 \times \mathrm{g}$, at $4^{\circ} \mathrm{C}$ for 15 minutes. The supernatant was harvested and used for the determination of glutathione peroxidase (GPx) activity using the Cayman GPx assay kit (Cayman).

\section{Lipid peroxidation assay}

Gastric mucosal tissues were sonicated in PBS and chloroform. Hydroperoxide was extracted from the mixture using an extraction buffer. The mixture was centrifuged at $1,500 \times g$, at $0^{\circ} \mathrm{C}$ for 10 minutes. The chloroform layer at the bottom of the tube was aspirated, mixed with a chromogenic reagent, and allowed to stand at room temperature for 5 minutes. Lipid peroxidation (LPO) activity was determined from the mixture using the LPO assay kit (Cayman).

\section{Prostaglandin E2 assay}

Gastric mucosal tissues were weighed and homogenized in PBS buffer at $4^{\circ} \mathrm{C}$. The homogenates were then centrifuged at $13,400 \times g$ for 10 minutes and the supernatants used for the determination of prostaglandin E2 (PGE2) using the PGE2 Express Enzyme Immunoassay Kit (Cayman), according to the manufacturer's instruction. The PGE2 concentrations were expressed as $\mathrm{pg} / \mathrm{mL}$.

\section{Cytokine activity assay}

Determination of the levels of gastric mucosal tumor necrosis factor alpha (TNF- $\alpha$ ), interleukin (IL)-6, and IL-10 was done using the gastric mucosal homogenates. Briefly, tissue homogenate was centrifuged at 3,000× $g$ for 10 minutes and the supernatant was used for the detection of cytokine levels using commercial enzyme-linked immunosorbent assay kits for TNF- $\alpha$ (http://www.cusabio. com/ELISA-Kit/Rat-TNF-\%CE\%B1-ELISA-kit-109331. html), IL-6 (http://www.cusabio.com/ELISA-Kit/RatInterleukin-6IL-6-ELISA-KIT-84597.html), and IL-10 (http://www.cusabio.com/ELISA-Kit/Rat-Interleukin10IL-10-ELISA-KIT-84236.html) (Cusabio Biotech Co. Ltd, Cusabio Biotech Co Ltd, Hubei, People's Republic of China). 


\section{Statistical analysis}

All values are reported as mean \pm standard error of the mean. Statistical differences between groups were determined by one-way analysis of variance using Kruskal-Wallis test for comparisons of histological and immunohistochemical data, while a one-way analysis of variance with Tukey's post hoc test was employed for other parameters. GraphPad Prism 6.0 (GraphPad Software, Inc., La Jolla, CA, USA) was used for the analysis and significant differences between mean values were determined at $P<0.05$.

\section{Results}

\section{In vitro cytotoxicity}

The cytotoxic effect of MECE on J774A.1 cells is shown in Figure 1. At 200 and $400 \mu \mathrm{g} / \mathrm{mL}$, MECE was not toxic to J774A.1 cells. This suggests that MECE is safe to be used in these cells.

\section{Dosage selection}

Since no adverse effects were observed following acute toxicity studies and the extract proved nontoxic to J774A.1 cells in vitro, MECE doses of 200 and $400 \mathrm{mg} / \mathrm{kg}$ body weight were chosen for the in vivo experiments.

\section{Gastric acid secretion}

The MECE and omeprazole pretreatment significantly $(P<0.05)$ reduced the volume and total acidity of gastric juice at 4 hours posttreatment (Table 1). While the omeprazole group and MECE $200 \mathrm{mg} / \mathrm{kg}$ group had comparable volumes of gastric juice, the omeprazole group had a higher $(P<0.05)$ gastric juice $\mathrm{pH}$ than MECE at 200 and $400 \mathrm{mg} / \mathrm{kg}$. However, total acidity was comparable between the omeprazole group

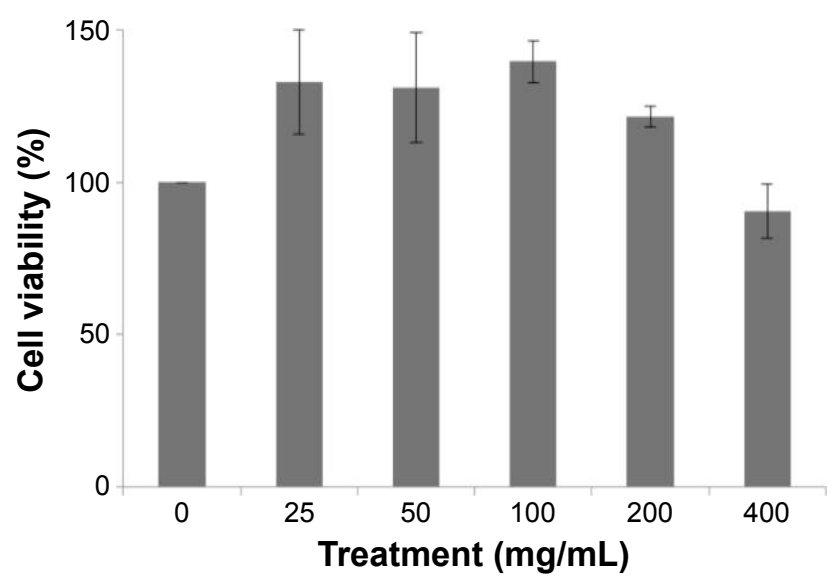

Figure I Cytotoxic effect of MECE on J774A.I cells. Abbreviation: MECE, methanolic extract of Clausena excavata leaves. and MECE $200 \mathrm{mg} / \mathrm{kg}$ group, while it was lower $(P<0.05)$ in the MECE $400 \mathrm{mg} / \mathrm{kg}$ group.

\section{Gastric mucosa}

At 200 and $400 \mathrm{mg} / \mathrm{kg}$ body weight, MECE significantly $(P<0.05)$ inhibited ulcer formation by $92.6 \%$ and $87.8 \%$, respectively (Table 2; Figure 2). There was gross evidence of flattening of gastric mucosa folds and reduction in mucosal damage in the rats upon pretreatment with MECE and omeprazole. The result showed that MECE is protective toward the development of gastric ulcers.

\section{Gastric content, $\mathrm{pH}$, and mucus weight}

Periodic acid-Schiff-stained gastric mucosal tissues showing mucus production are presented in Figure 3. Pretreatment with MECE and omeprazole increased mucus content of the gastric mucosa, with the effect being more pronounced $(P<0.05)$ in $400 \mathrm{mg} / \mathrm{kg}$ body weight MECE than other treatments. The $\mathrm{pH}$ of the gastric content of rats treated with MECE was significantly $(P<0.05)$ higher than that of the untreated rats with ulcer (Table 2).

\section{Gastric tissue lesion scoring}

Histopathologically, rats with untreated ulcers showed extensive gastric lesions with submucosal edema and leukocyte infiltration. The ulcer control rats had the highest lesion scores among groups. Pretreatment with MECE significantly $(P<0.05)$ reduced ulceration in the gastric mucosa, as evident by the decrease in ulcer area, reduction or complete absence of edema and leucocyte infiltration (Figure 4; Table 3). Rats treated with MECE $400 \mathrm{mg} / \mathrm{kg}$ showed the least distribution of lesions $(P<0.05)$, when compared with the omeprazole and MECE $200 \mathrm{mg} / \mathrm{kg}$ groups, had comparable $(P>0.05)$ lesion distribution.

\section{Gastric mucus}

MECE and omeprazole pretreatments resulted in significantly $(P<0.05)$ enhanced mucus secretion over the entire lining of rat gastric mucosa with ulcer. However, untreated ulcers did not show evidence of mucus secretion on the gastric mucosa (Figure 3).

\section{Bax, HSP70, and TGF- $\beta$ expression}

Unlike in untreated ulcerated gastric mucosa which showed upregulation of Bax protein, the MECE-treated mucosa showed a downregulation of this protein (Figure 5; Table 4). On the other hand, the HSP70 expression was upregulated 
Table I Effect of methanolic Clausena excavata leaf extract treatment on gastric secretory effects of rats

\begin{tabular}{llll}
\hline Pretreatment & $\begin{array}{l}\text { Volume of gastric } \\
\text { juice }(\mathbf{m L})\end{array}$ & $\begin{array}{l}\text { pH of gastric } \\
\text { juice }\end{array}$ & $\begin{array}{l}\text { Total acidity } \\
(\mathbf{m E q} / \mathbf{L})\end{array}$ \\
\hline $5 \%$ Tween $\left.20 \mathrm{v} / \mathrm{v}(\text { normal control })^{2}\right)$ & $5.2 \pm 0.5$ & $1.5 \pm 0.1$ & $3,717.9 \pm 146.7$ \\
Omeprazole $(20 \mathrm{mg} / \mathrm{kg} \mathrm{Bwt})$ & $2.2^{*} \pm 0.3$ & $3.8^{*} \pm 0.1$ & $1,976.7^{*} \pm 389.0$ \\
MECE $(200 \mathrm{mg} / \mathrm{kg} \mathrm{Bwt})$ & $2.6^{*} \pm 0.2$ & $2.6^{*} \pm 0.1$ & $1,579.0^{*} \pm 236.0$ \\
MECE $(400 \mathrm{mg} / \mathrm{kg} \mathrm{Bwt})$ & $1.7^{*} \pm 0.3$ & $2.7^{*} \pm 0.3$ & $1,102.4^{*} \pm 82.2$ \\
\hline
\end{tabular}

Notes: All the values are expressed as mean \pm standard error of the mean. ${ }^{a}$ Treated with $5 \%$ Tween 20 only. $*$ Significant differences at $P<0.05$ compared with normal control. Abbreviations: Bwt, body weight; MECE, methanolic extract of Clausena excavata leaves.

Table 2 Effect of methanolic Clausena excavata leaf extract treatment on pH of gastric content, gastric ulcer area, and ulcer inhibition in rats

\begin{tabular}{lllll}
\hline Pretreatment & $\begin{array}{l}\text { pH of gastric } \\
\text { content }\end{array}$ & $\begin{array}{l}\text { Mucus } \\
\text { content }\end{array}$ & $\begin{array}{l}\text { Ulcer area } \\
\left(\mathbf{m m}^{2}\right)\end{array}$ & $\begin{array}{l}\text { Inhibition } \\
(\%)\end{array}$ \\
\hline $5 \%$ Tween $20 \mathrm{v} / \mathrm{v}\left(\right.$ normal control $\left.{ }^{2}\right)$ & $6.8 \pm 0.2$ & $0.9 \pm 0.5$ & 0 & $\mathrm{NA}$ \\
Ethanol $(5 \mathrm{~mL} / \mathrm{kg} \mathrm{Bwt})($ untreated control) & $3.1 \pm 0.1$ & $0.5 \pm 0.1$ & $460.8 \pm 65.1$ & $\mathrm{NA}$ \\
Omeprazole $(20 \mathrm{mg} / \mathrm{kg} \mathrm{Bwt})$ & $7.1^{*} \pm 0.3$ & $0.8 * \pm 0.1$ & $59.4^{*} \pm 23.8$ & 86.3 \\
MECE $(200 \mathrm{mg} / \mathrm{kg} \mathrm{Bwt})$ & $6.2^{*} \pm 0.1$ & $0.7 * \pm 0.2$ & $34.2 * \pm 14.5$ & 92.6 \\
MECE $(400 \mathrm{mg} / \mathrm{kg} \mathrm{Bwt})$ & $6.0 * \pm 0.3$ & $1.0^{*} \pm 0.03$ & $56.2 * \pm 23.9$ & 87.8 \\
\hline
\end{tabular}

Notes: All the values are expressed as mean \pm standard error of the mean. ${ }^{a}$ Treated with $5 \%$ Tween 20 only. $*$ Significant differences at $P<0.05$ compared with untreated control.

Abbreviations: Bwt, body weight; MECE, methanolic extract of Clausena excavata leaves; NA, not applicable.
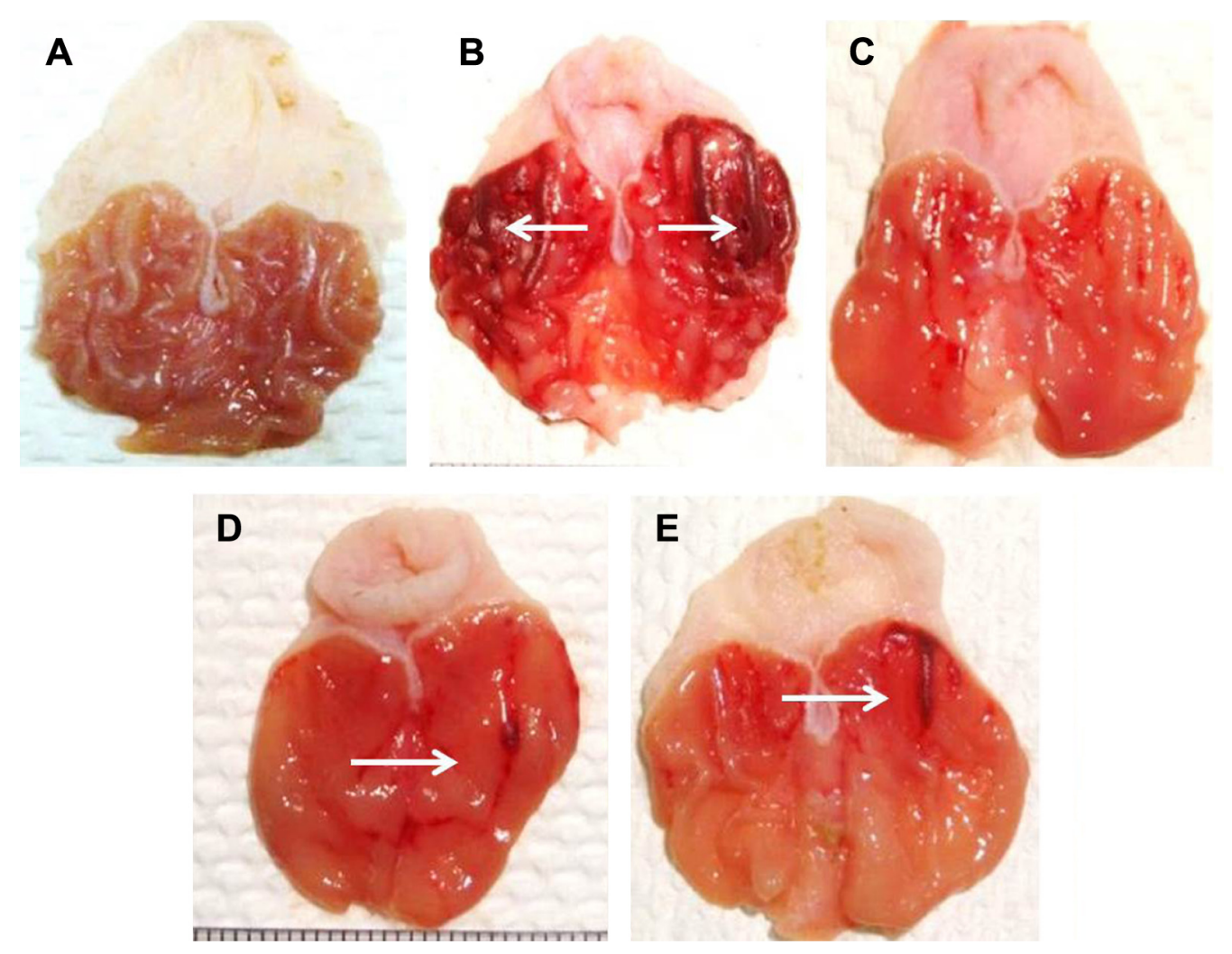

Figure 2 Protective effect of methanolic extract of Clausena excavata leaf on ethanol-induced gastric mucosal lesions in rats.

Notes: Pretreatment with (A) $5 \%$ Tween $20,5 \mathrm{~mL} / \mathrm{kg}$ body weight (normal control); (B) $5 \mathrm{~mL} / \mathrm{kg}$ body weight, absolute ethanol (ulcer control) showing severe ulceration of the gastric mucosa (arrows); (C) $20 \mathrm{mg} / \mathrm{kg}$ body weight omeprazole; (D) 200 and (E) $400 \mathrm{mg} / \mathrm{kg}$ body weight extract showing very mild ulceration of the gastric mucosa (arrow). 

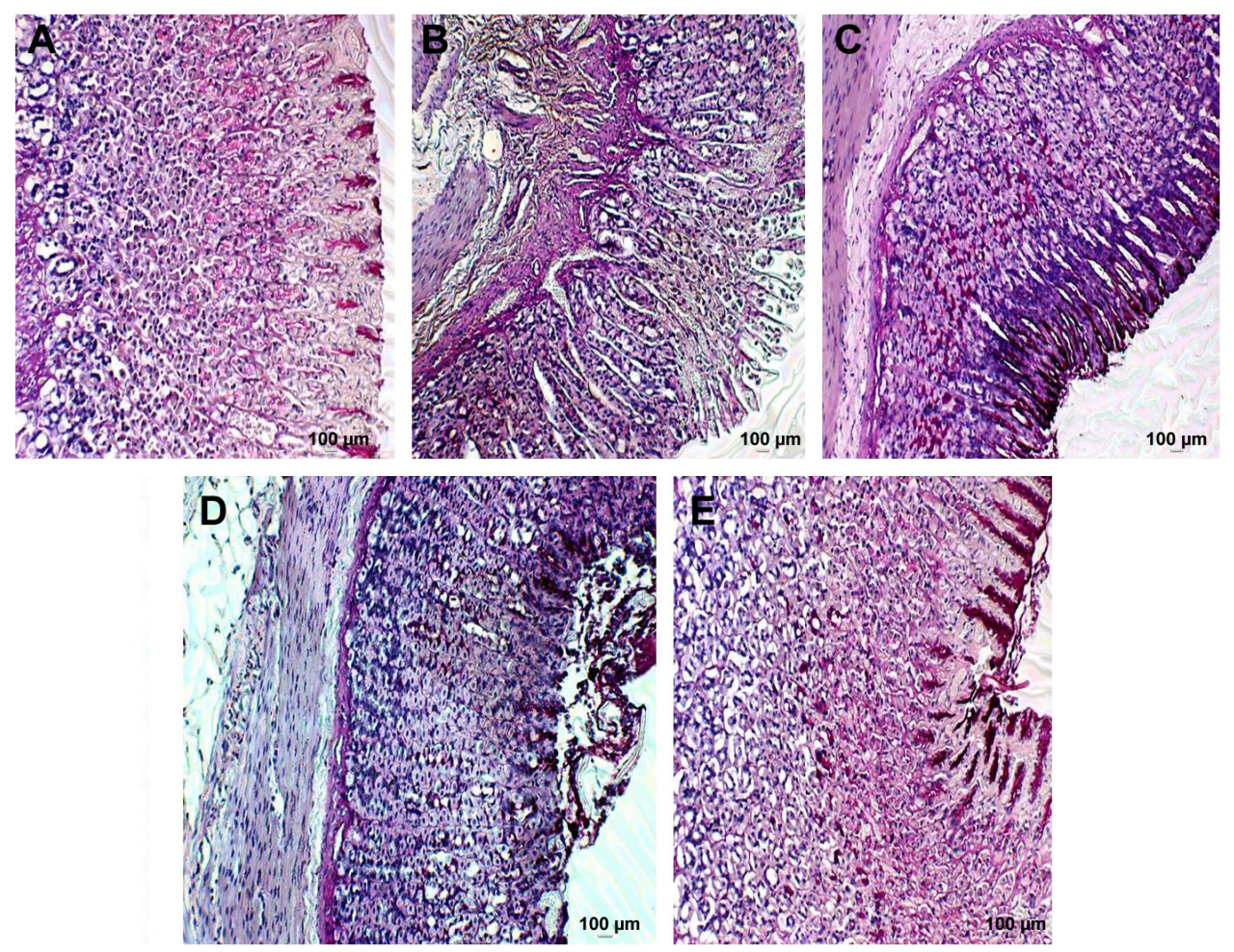

Figure 3 Rat gastric tissue stained showing mucus production.

Notes: (A) Normal gastric tissue (negative control); (B) untreated ethanol-induced gastric ulcer (positive control); and pretreatment with (C) $20 \mathrm{mg} / \mathrm{kg}$ body weight omeprazole, (D) 200 and (E) $400 \mathrm{mg} / \mathrm{kg}$ body weight methanolic Clausena excavata leaf extract. Magenta coloration in the epithelial cells indicates increased gastric gland secretion. The most intense coloration was observed in gastric tissue treated with $400 \mathrm{mg} / \mathrm{kg}$ body weight extract (periodic acid-Schiff stain, $\times 200$ ).
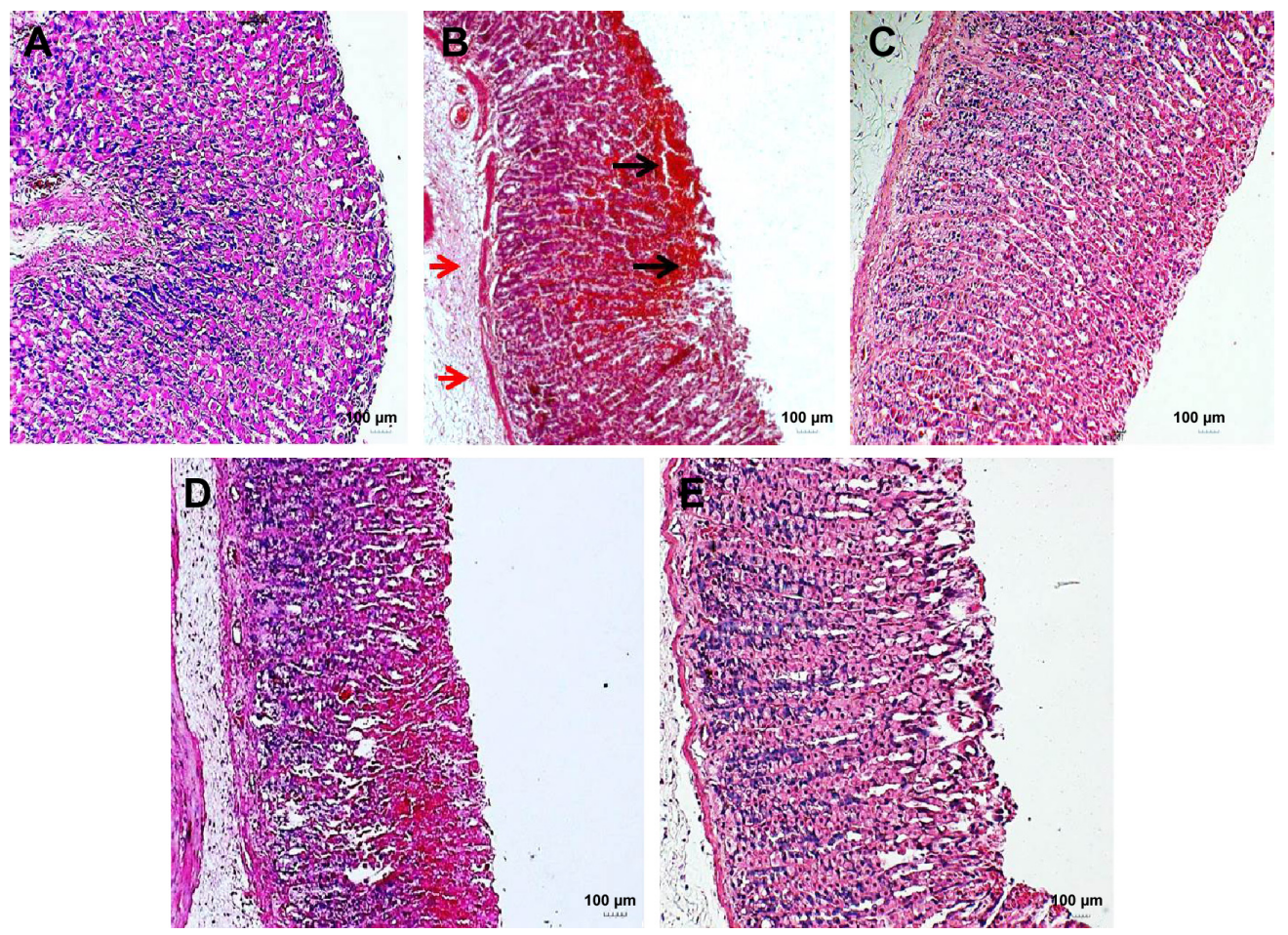

Figure 4 Untreated gastric ulcer with extensive hemorrhages (black arrows), and sub-mucosal oedema (red arrows).

Notes: (A) Normal gastric tissue; (B) untreated gastric ulcer with extensive hemorrhages (black arrows); and pretreated with (C) $20 \mathrm{mg} / \mathrm{kg}$ body weight omeprazole, (D) 200 (E) and $400 \mathrm{mg} / \mathrm{kg}$ body weight methanolic Clausena excavata leaf extract (H\&E stain, $\times 200$ ).

Abbreviation: H\&E, hematoxylin and eosin. 
Table 3 Gastric tissue lesion score in rat gastric tissue with ulcer treated with methanolic Clausena excavata leaf extract

\begin{tabular}{llllll}
\hline Treatment & $\begin{array}{l}\text { Hemorrhage } \\
\text { (no of } \\
\text { squares) }\end{array}$ & $\begin{array}{l}\text { Submucosal } \\
\text { edema (no of } \\
\text { squares) }\end{array}$ & $\begin{array}{l}\text { Epithelial cell } \\
\text { loss (no of } \\
\text { squares) }\end{array}$ & $\begin{array}{l}\text { Inflammatory } \\
\text { cell infiltration } \\
\text { (no of squares) }\end{array}$ & $\begin{array}{l}\text { Total } \\
\text { lesion area } \\
\left(\mathbf{m m}^{2}\right)\end{array}$ \\
\hline $5 \%$ Tween $20 \mathrm{v} / \mathrm{v}\left(\mathrm{normal}\right.$ control $\left.^{2}\right)$ & 0 & 0 & 0 & 0 & 0 \\
Ethanol $(5 \mathrm{~mL} / \mathrm{kg} \mathrm{Bwt})($ untreated control) & $2.8 \pm 0.2$ & $2.6 \pm 0.3$ & $2.7 \pm 0.4$ & $2.3 \pm 0.1$ & 10.4 \\
Omeprazole $(20 \mathrm{mg} / \mathrm{kg} \mathrm{Bwt)}$ & $1.5^{*} \pm 0.4$ & $1.5^{*} \pm 0.2$ & $1.4^{*} \pm 0.1$ & $1.6^{*} \pm 0.3$ & $6.1^{*}$ \\
MECE $(200 \mathrm{mg} / \mathrm{kg} \mathrm{Bwt})$ & $1.6^{*} \pm 0.3$ & $1.4^{*} \pm 0.1$ & $1.5^{*} \pm 0.3$ & $1.3^{*} \pm 0.4$ & $5.8^{*}$ \\
MECE $(400 \mathrm{mg} / \mathrm{kg} \mathrm{Bwt)}$ & $0.7^{*} \pm 0.1$ & $0.9^{*} \pm 0.1$ & $0.6^{*} \pm 0.2$ & $0.7^{*} \pm 0.1$ & $2.9^{*}$ \\
\hline
\end{tabular}

Notes: One unit square is the $2 \times 2 \mathrm{~mm}^{2}$ area of tissue with lesion. All values are expressed as mean \pm standard error of the mean. ${ }^{\mathrm{a}}$ Treated with $5 \%$ Tween 20 only. *Significant differences at $\mathrm{P}<0.05$ compared with untreated control.

Abbreviations: Bwt, body weight; MECE, methanolic extract of Clausena excavata leaves.

in both omeprazole- and MECE-treated groups. The effect of MECE on HSP70 expression was dose-dependent, with greater expression at the higher dose of the extract (Figure 6; Table 5). TGF-B was upregulated in all treatment groups, but higher $(\mathrm{P}<0.05)$ in the omeprazole group. (Figure 7 , Table 6).

\section{PGE2 and antioxidant activity}

As shown in Figure 8, the SOD, CAT, and GPx activities and PGE2 concentration were significantly $(P<0.05)$ higher in the ulcerated gastric tissue treated with MECE and omeprazole than in the untreated tissue. In contrast, the extract produced a significantly $(P<0.05)$ lower LPO activity in all pretreated than untreated gastric tissues with ulcer. The results show that the antioxidant activity exhibited by MECE in ulcerated gastric tissue is greater than that of tissues pretreated with omeprazole.

\section{TNF- $\alpha$, IL- 6 , and IL- I 0 enzyme activities}

MECE demonstrated an immune-modulatory effect in the gastric tissue by reducing the levels of TNF- $\alpha$ and IL- 6 , while the level of IL-10 was increased (Figure 9).


Figure 5 Rat gastric tissues showing Bax protein expression.

Notes: (A) Negative control; (B) untreated ethanol-induced ulcer showing overexpression of Bax proteins in the epithelial cells; pretreatment with (C) 20 mg/kg body weight omeprazole, (D) 200 and (E) $400 \mathrm{mg} / \mathrm{kg}$ body methanolic Clausena excavata leaf extract showing reduced Bax protein expression in the apical epithelial cells (immunoperoxidase stain, $\times 200$ ). 
Table 4 Area of rat gastric mucosal tissue positive for Bax protein staining after treatment with methanolic Clausena excavata leaf extract

\begin{tabular}{lll}
\hline Treatment & $\begin{array}{l}\text { Stained area } \\
\left(\times 10^{3}\right)\left(\mu \mathbf{m}^{2}\right)\end{array}$ & \% Area \\
\hline $5 \%$ Tween $20 \mathrm{v} / \mathrm{v}\left(\right.$ normal control $\left.{ }^{2}\right)$ & 0.00 & 0 \\
Ethanol $(5 \mathrm{~mL} / \mathrm{kg} \mathrm{Bwt})$ (untreated control) & $48.0^{*} \pm 0.4$ & 40 \\
Omeprazole $(20 \mathrm{mg} / \mathrm{kg} \mathrm{Bwt})$ & $21.2^{*} \pm 2.6$ & 17 \\
MECE $(200 \mathrm{mg} / \mathrm{kg} \mathrm{Bwt})$ & $15.1^{*} \pm 2.1$ & 12 \\
MECE $(400 \mathrm{mg} / \mathrm{kg} \mathrm{Bwt})$ & $4.2^{*} \pm 1.3$ & 4 \\
\hline
\end{tabular}

Notes: All values are expressed as mean \pm standard error of the mean. ${ }^{2}$ Treated with $5 \%$ Tween 20 only. *Significant differences at $P<0.05$ compared with normal control.

Abbreviations: Bwt, body weight; MECE, methanolic extract of $C$. excavato leaves.

\section{Discussion}

Gastric ulcers are caused by an imbalance between the intrinsic protective mechanism and disease-causing endogenous and exogenous factors in the environment of the stomach. ${ }^{22}$ Gastritis and gastric ulcers can be effectively treated with several drugs available in the market. However, there are several natural plant products purported to be also effective in the treatment of gastric ulcers, among which are products from the C. excavata plant. The advantage of using natural products is that they have fewer side effects than the commercial drugs. Currently, the antiulcer property of $C$. excavata is yet to be corroborated.

In our recent study, MECE was found to have significant antioxidant activities, which was attributed to its rich phenolic/flavonoid content. ${ }^{8}$ The MECE was also found to be nontoxic to the J774A.1 macrophage cell line, even at high doses. Since macrophages produce macrophage colony-stimulating factor, which plays a significant role in healing of gastric ulcers through promotion of angiogenesis, treatment of gastric ulcers with MECE should not inhibit healing. ${ }^{23}$

Histopathological evaluation showed that MECE inhibits leukocyte infiltration, hemorrhage, edema, and epithelial cell loss in rat gastric tissues with ethanol-induced gastric ulcer. These changes suggest that the extract reduces development of pathological lesions associated with gastric ulcers, a finding that concurs with those of earlier studies. In fact, the healing and lesion-inhibition effects of MECE were suggested to be through its antioxidant and anti-inflammatory activities. ${ }^{8,24,25}$

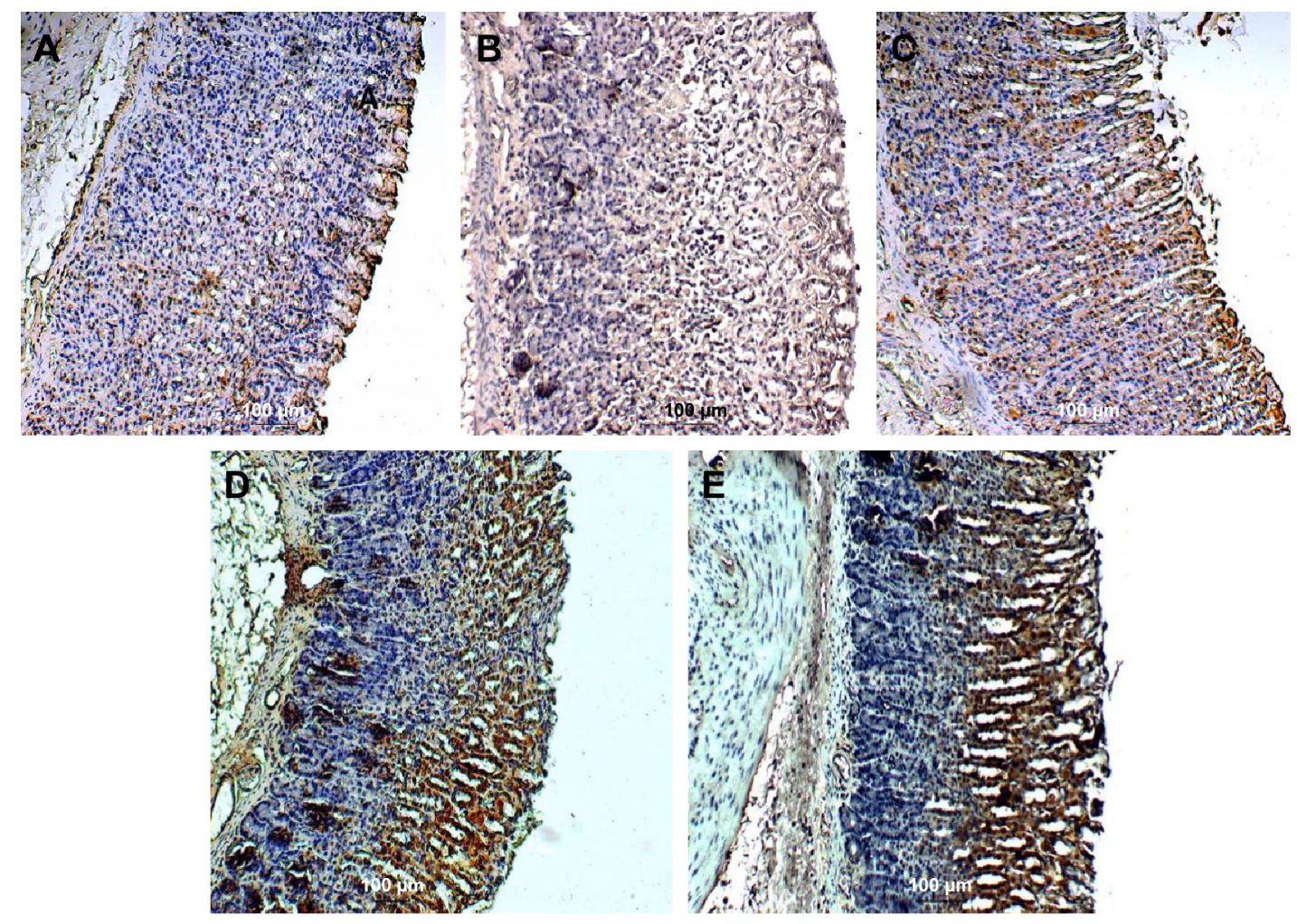

Figure 6 Rat gastric tissue showing HSP70 expression.

Notes: (A) Negative control; (B) untreated ethanol-induced ulcer showing underexpression of HSP70 proteins in the epithelial cells; pretreatment with (C) 20 mg/kg body weight omeprazole, (D) 200 and (E) $400 \mathrm{mg} / \mathrm{kg}$ body methanolic Clausena excavata leaf extract. Increased HSP70 expression was seen after treatment with $400 \mathrm{mg} / \mathrm{kg}$ body weight extract (immunoperoxidase stain, $\times 100$ ).

Abbreviation: HSP70, heat shock protein 70 . 
Table 5 Area of rat gastric mucosal tissue positive for HSP70 protein immunoperoxidase staining after treatment with methanolic Clausena excavata leaf extract

\begin{tabular}{lll}
\hline Treatment & $\begin{array}{l}\text { Stained area } \\
\left(\times 10^{3}\right)\left(\mu \mathbf{m}^{2}\right)\end{array}$ & $\%$ area \\
\hline $5 \%$ Tween $20 \mathrm{v} / \mathrm{v}\left(\right.$ normal control $\left.{ }^{2}\right)$ & $5.4 \pm 2.2$ & 4 \\
Ethanol $(5 \mathrm{~mL} / \mathrm{kg} \mathrm{Bwt})$ (untreated control) & $6.3 \pm 3.1$ & 5 \\
Omeprazole (20 mg/kg Bwt) & $32.4^{*} \pm 2.9$ & 22 \\
MECE (200 mg/kg Bwt) & $36.4^{*} \pm 3.3$ & 25 \\
MECE (400 mg/kg Bwt) & $46.3^{*} \pm 3.7$ & 33 \\
\hline
\end{tabular}

Notes: All the values are expressed as mean \pm standard error of the mean. ${ }^{\mathrm{a}}$ Treated with $5 \%$ Tween 20 only. *Significant differences at $P<0.05$ compared with normal control.

Abbreviations: Bwt, body weight; $\mathrm{HSP70}$, heat shock protein 70; MECE, methanolic extract of $C$. excavata leaves.

Current therapeutic strategies in peptic ulcer treatment are aimed at either suppression of gastric acid secretion or enhancement of effect of gastroprotective factors. ${ }^{26}$ To investigate the gastroprotective effect of MECE, this study used the rat pylorus ligature model. Ligation of the pylorus causes stasis of gastric acid resulting in gastric ulcer development. ${ }^{27}$
Using this model, MECE was found to reduce the volume and total acidity of the gastric juice, suggesting that the extract inhibited production and secretion of gastric juice.

Ethanol causes development of necrotic lesions in the gastric mucosa by decreasing mucus and bicarbonate and increasing hydroperoxide and superoxide anion production, thereby inducing gastric ulcer when given orally to the rat. ${ }^{27,28}$ Using the ethanol-induced rat gastric ulcer model, MECE was found to protect the gastric mucosa from development of ulcers; this effect may be attributable to the free radical scavenging properties of the extract. ${ }^{8,29}$ Reactive oxygen species (ROS) are generated at a low rate in normal cellular metabolism and these oxidative radicals are scavenged by the antioxidant defense system of the body, namely, SOD, GPx, and CAT. Since the accumulation of ROS increases LPO, the LPO content in the gastric mucosa can be used as a biomarker for development of ROS-mediated gastric mucosal lesions. ${ }^{30-32}$ In our study, MECE increased SOD, GPx, and CAT and decreased LPO contents in the gastric mucosa,

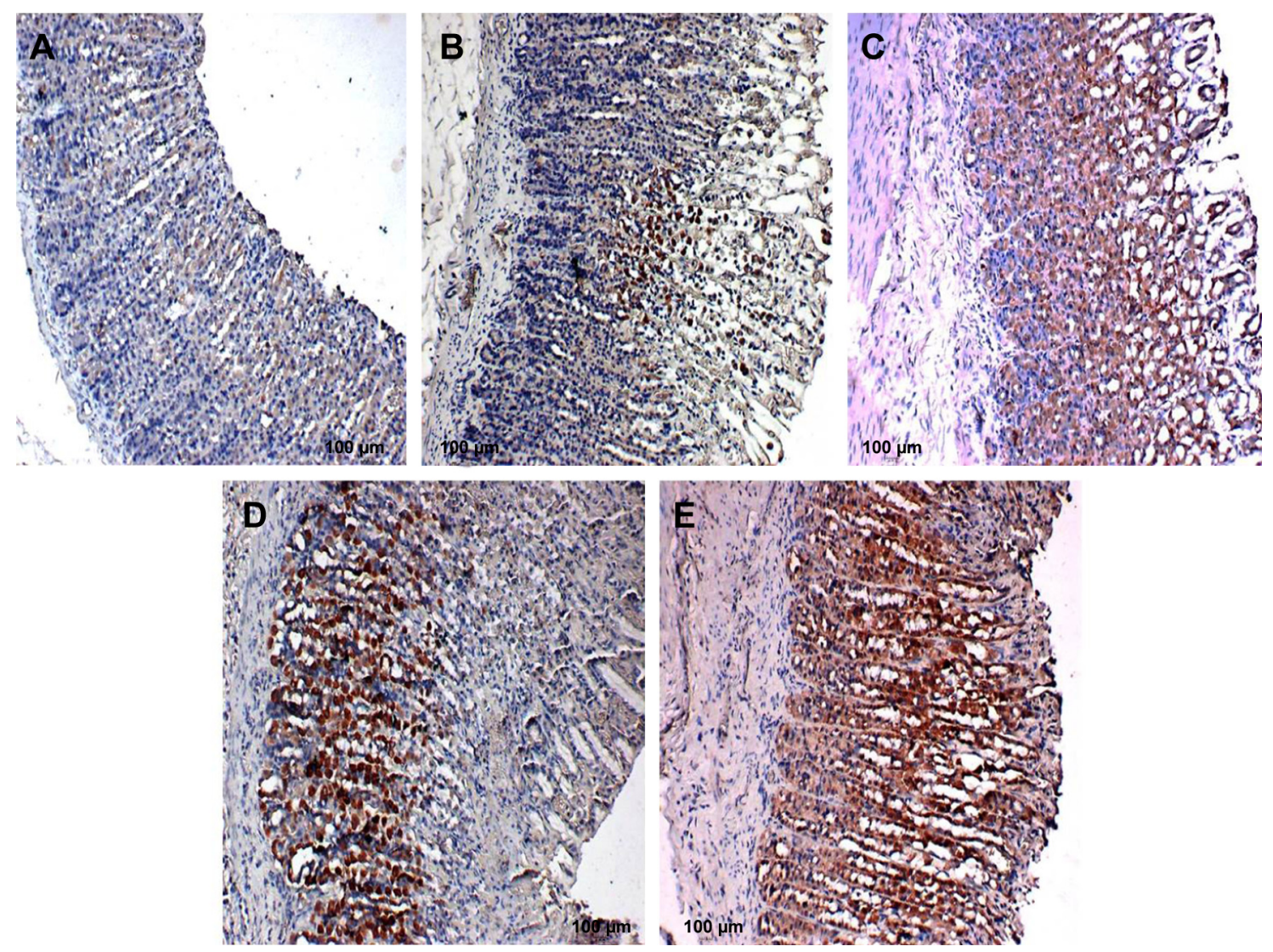

Figure 7 Rat gastric tissues showing TGF- $\beta$ protein expression.

Notes: (A) Negative control; (B) untreated ethanol-induced ulcer showing underexpression of TGF- $\beta$ proteins in the epithelial cells; pretreatment with (C) 20 mg/kg body weight omeprazole, (D) 200 and (E) $400 \mathrm{mg} / \mathrm{kg}$ body weight methanolic Clausena excavata leaf extract showing increased TGF- $\beta$ protein expression in the apical epithelial cells (immunoperoxidase stain, $\times 200$ ).

Abbreviation: TGF- $\beta$, transforming growth factor-beta. 

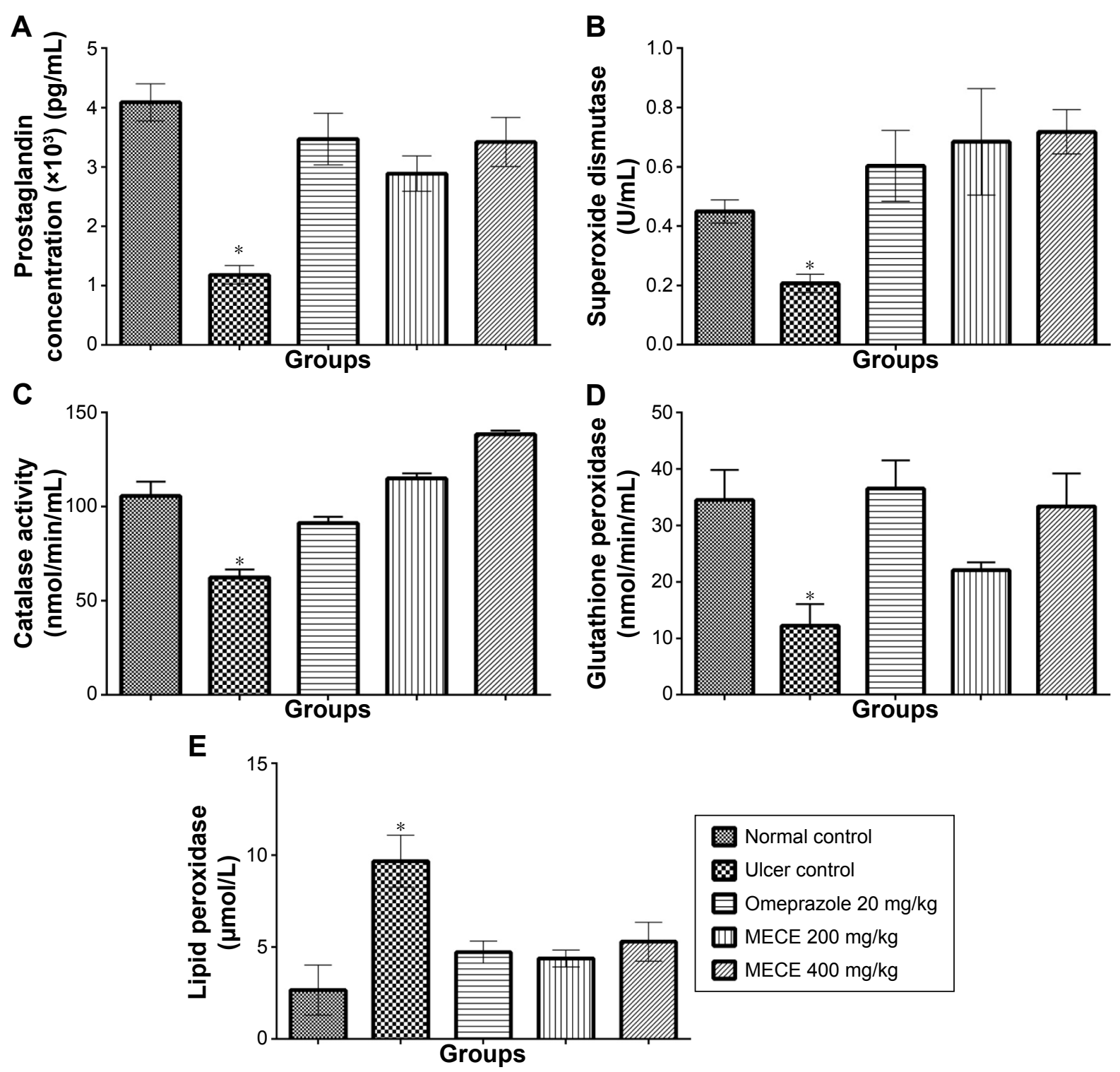

Figure 8 Expression of prostaglandin and antioxidant enzyme parameters in rat gastric tissues with ulcer after Clausena excavata leaf extract treatment.

Notes: (A) Prostaglandin E2, (B) superoxide dismutase, (C) catalase, (D) glutathione peroxidase, (E) LPO activities in ulcerated rat gastric mucosa tissues after pretreatment with MECE. All values are expressed as mean \pm standard error of the mean. *Significant difference at $P<0.05$ upon comparison with the ulcer control.

Abbreviations: Bwt, body weight; LPO, lipid peroxidation; MECE, methanolic extract of $C$. excavata leaves.

further confirming that the extract has gastroprotective properties against the development of ethanol-induced ulcers. Other plant extracts have been shown to produce similar antioxidant effects in ethanol-induced gastric ulcer models by decreasing LPO and increasing CAT, SOD and GPX activities. ${ }^{4,5,33}$

The gastric mucosa serves as a physical barrier against external and internal ulcerative agents through several mechanisms of protection. ${ }^{34}$ One of these mechanisms is the production of mucus lining the mucosa. Decreased mucus and acid production by the stomach are among the factors contributing to the development of gastric ulcers and inhibition of healing. ${ }^{2}$ In our study, MECE was found to increase the production of gastric mucus as well as the $\mathrm{pH}$ of gastric juice, which prevented the development of gastric ulcers. Prostaglandins control gastric acid secretion and enhance gastric mucus and bicarbonate production, thus playing a significant protective role by conferring the gastric mucosa the ability to resist injury caused by noxious compounds. ${ }^{35,36}$ The ulcerated gastric mucosa showed a higher level of PGE2 after MECE treatment than in untreated rats. This suggests that enhancement of PGE2 activity is another mechanism through which MECE reduces ulceration in the gastric mucosa. Thus, it can be said that the gastroprotective effect of MECE may be 


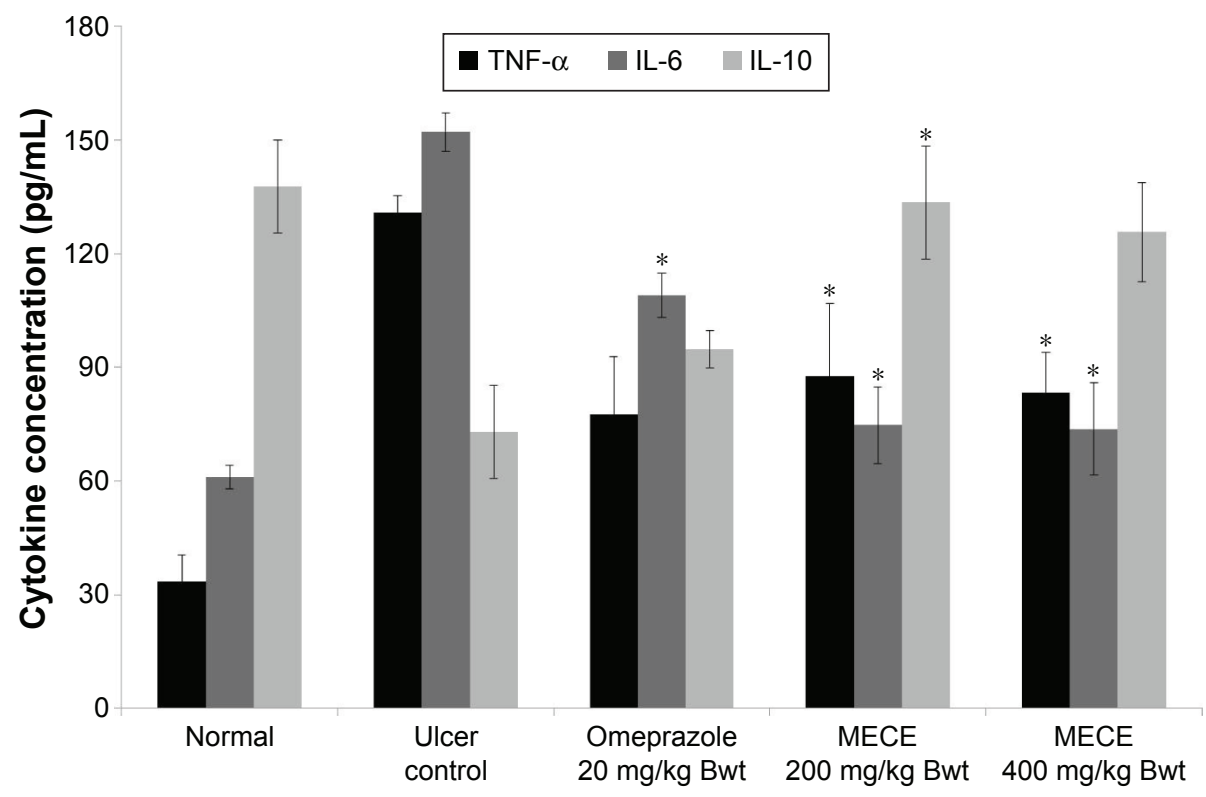

Figure 9 Effect of MECE on TNF- $\alpha$, IL-6, and IL- 10 levels in gastric tissue of ethanol-induced ulcerated rats.

Notes: Results are expressed as mean \pm SEM. $* P<0.05$, statistically significant as compared with other groups.

Abbreviations: Bwt, body weight; IL, interleukin; MECE, methanolic extract of Clausena excavata leaves; SEM, standard error of the mean; TNF- $\alpha$, tumor necrosis factor alpha.

partly due to the coumarin in the extract, which stimulates gastric prostaglandin and mucus production. ${ }^{8,37}$

The susceptibility of cells to apoptosis depends on the balance between apoptosis-promoting and apoptosis-suppressing factors. ${ }^{38}$ One of the mechanisms in gastric ulceration is induction of apoptosis of the gastric mucosal cells. ${ }^{39}$ Thus, another means of inhibition of gastric ulceration is by the prevention of premature mucosal cell apoptosis.

Previous studies showed that the Bax protein, a proapoptotic protein, was upregulated in untreated rats with induced gastric ulcer. ${ }^{40-42}$ The MECE caused a downregulation of Bax protein in the rat gastric ulcer. This suggests that MECE inhibits premature cell death in the gastric mucosa, an effect

Table 6 Area of rat gastric mucosal tissue positive for TGF- $\beta$ protein immunoperoxidase staining after treatment with methanolic Clausena excavata leaf extract

\begin{tabular}{lll}
\hline Treatment & $\begin{array}{l}\text { Stained area } \\
\left(\times 10^{3}\right)\left(\mu \mathrm{m}^{2}\right)\end{array}$ & $\%$ Area \\
\hline $5 \%$ Tween $20 \mathrm{v} / \mathrm{v}\left(\right.$ normal control $\left.{ }^{2}\right)$ & $3.6 \pm 0.8$ & 3 \\
Ethanol $(5 \mathrm{~mL} / \mathrm{kg} \mathrm{Bwt})$ (untreated control) & $4.5 \pm 0.1$ & 4 \\
Omeprazole $(20 \mathrm{mg} / \mathrm{kg} \mathrm{Bwt})$ & $44.2^{*} \pm 0.9$ & 34 \\
MECE $(200 \mathrm{mg} / \mathrm{kg} \mathrm{Bwt})$ & $31.6^{*} \pm 2.3$ & 20 \\
MECE $(400 \mathrm{mg} / \mathrm{kg} \mathrm{Bwt})$ & $35 . I^{*} \pm 3.4$ & 24 \\
\hline
\end{tabular}

Notes: All the values are expressed as mean \pm standard error of the mean. ${ }^{2}$ Treated with $5 \%$ Tween 20 only. *Significant differences at $P<0.05$ compared with normal control.

Abbreviations: Bwt, body weight; MECE, methanolic extract of $C$. excavata leaves; TGF- $\beta$, transforming growth factor-beta. that is strongly associated with the gastroprotective property of the extract. HSP70 protein from the heat shock protein family is ubiquitously present in mammalian cells and this protein serves to defend cells from oxidative stress damage. In the cell, HSP70 preserves the functional structure of normal proteins while repairing or removing damaged proteins. In the gastric mucosa, ROS generation by ethanol impedes expression of HSP70, making the mucosal layer susceptible to ulcerative damage. ${ }^{43}$ However, treatment with MECE increased the expression of HSP70 in the gastric mucosa with ethanol-induced ulcer, which suggests it to be one of the many facets associated with the gastroprotective properties of MECE. Similar findings have been reported by other authors using different compounds and plant extracts. ${ }^{44}-47$ TGF- $\beta$ is one of the most important growth factors that have a healing effect on gastric ulcer through induction of cell migration and increased vascular proliferation, thereby enhancing deposition of extracellular matrix. In this study, we observed an increased expression of TGF- $\beta$ in the omeprazole-treated and MECE-treated groups. These findings were similar to those reported following administration of chalcone 1-(4-hydroxy-phenyl)-3-m-tolyl-propenone (HPTP) to rats having indomethacin-induced ulcer. ${ }^{48}$ The immunoreactivity effect of TGF- $\beta$ enhances the proliferation of epithelial cells in gastric glands. ${ }^{49,50}$

It has been shown by previous researchers that ethanol induces an inflammatory response that initiates a dynamic 
chain of immune responses associated with the release of vast amounts of inflammatory cytokines such as TNF- $\alpha$ and IL-6, which in turn produce increased quantity of ROS. ${ }^{51}$ TNF- $\alpha$, being a major proinflammatory cytokine produced by macrophages, attracts neutrophils to the site of gastric mucosal injury. ${ }^{52,53}$ IL-6 is another important proinflammatory cytokine shown to mediate immune response and acute inflammation. IL-6 activates granulocytes and agranulocytes, which in turn trigger a stress response in injured tissue. ${ }^{54,55}$ Sabat et $a 1^{55}$ suggested that IL-10 has the ability to suppress inflammatory response and inhibit TNF- $\alpha$ production. Previous reports showed that ethanol was able to increase proinflammatory cytokines and decrease anti-inflammatory cytokines in gastric tissue. ${ }^{56,57}$ Our results were in agreement with these observations, where exposure to ethanol showed elevated TNF- $\alpha$ and IL- 6 and decrease in IL-10 levels, compared to normal controls. However, MECE pretreatment inhibited depletion of IL-10 and elevation of TNF- $\alpha$ and IL- 6 levels, which shows its anti-inflammatory effect on ethanolinduced gastric ulcer in the rat. This also concurs with the earlier histological finding where less inflammatory responses were observed in MECE-treated rats with gastric ulcer.

\section{Conclusion}

This study shows the potential antiulcerogenic effects of MECE against ulcerative damage caused by ethanol. Furthermore, the present study shows that the gastroprotective properties of MECE may involve a number of mechanisms that include inhibition of gastric juice production, enhancement of gastric mucus secretion, increase in gastric juice $\mathrm{pH}$, stimulation of antioxidant enzyme activities, downregulation of Bax, and upregulation of HSP70 and TGF- $\beta$ protein expression in the gastric mucosa, as well as elevated TNF- $\alpha$ and IL- 6 and decrease in IL-10 levels. Based on these findings, MECE can be further explored as a potential therapeutic compound for the treatment of gastric ulcers.

\section{Acknowledgment}

This study was financially supported by the University of Malaya PPP Grant (no PG059-2013A).

\section{Author contributions}

All authors contributed toward data analysis, drafting and revising the paper and agree to be accountable for all aspects of the work.

\section{Disclosure}

The authors report no conflicts of interest in this work.

\section{References}

1. Obidike IC, Emeje MO. Microencapsulation enhances the antiulcerogenic properties of Entada africana leaf extract. J Ethnopharmacol. 2011;137(1):553-561.

2. Brzozowski T, Konturek PC, Konturek SJ, et al. Role of gastric acid secretion in progression of acute gastric erosions induced by ischemia-reperfusion into gastric ulcers. Eur J Pharmacol. 2000;398(1):147-158.

3. Kumar A, Singh V, Chaudhary AK. Gastric antisecretory and antiulcer activities of Cedrus deodara (Roxb.) Loud in Wistar rats. J Ethnopharmacol. 2011;134(2):294-297.

4. Awaad AS, El-Meligy RM, Soliman GA. Natural products in treatment of ulcerative colitis and peptic ulcer. J Saud Chem Soc. 2013;17(1): 101-124.

5. Repetto MG, Llesuy SF. Antioxidant properties of natural compounds used in popular medicine for gastric ulcers. Braz J Med Biol Res. 2002; 35(5):523-534.

6. Adinortey MB, Ansah C, Galyuon I, Nyarko A. In vivo models used for evaluation of potential antigastroduodenal ulcer agents. Ulcers. 2013;2013:796405.

7. Zheng XL, Wei JH, Sun W, Li RT, Liu SB, Dai HF. Ethnobotanical study on medicinal plants around Limu Mountains of Hainan Island, China. J Ethnopharmacol. 2013;148(3):964-974.

8. Albaayit SFA, Abba Y, Abdullah R, Abdullah N. Evaluation of antioxidant activity and acute toxicity of Clausena excavata leaves extract. Evid Based Complement Alternat Med. 2014;2014:975450.

9. Kumar R, Saha A, Saha D. A new antifungal coumarin from Clausena excavata. Fitoterapia. 2012;83(1):230-233.

10. Manosroi A, Saraphanchotiwitthaya A, Manosroi J. Immunomodulatory activities of fractions from hot aqueous extract of wood from Clausena excavata. Fitoterapia. 2004;75(3):302-308.

11. Rahman MT, Alimuzzaman M, Shilpi JA, Hossain MF. Antinociceptive activity of Clausena excavata leaves. Fitoterapia. 2002;73(7):701-703.

12. Academy of Science, USA. Guide for the Care and Use of Laboratory Animals. Available from: http://www.grants.nih.gov/grants/olaw/ guide-for-the-care-and-use-of-laboratory-animals.pdf. Accessed on January 24, 2016.

13. Shay H. A simple method for the uniform production of gastric ulceration in the rat. Gastroenterology. 1945;5:43-61.

14. Tan PV, Nyasse B, Dimo T, Mezui C. Gastric cytoprotective anti-ulcer effects of the leaf methanol extract of Ocimum suave (Lamiaceae) in rats. J Ethnopharmacol. 2002;82(2):69-74.

15. Srivastava V, Viswanathaswamy AH, Mohan G. Determination of the antiulcer properties of sodium cromoglycate in pylorus-ligated albino rats. Indian J Pharmacol. 2010;42(3):185-188.

16. Potrich FB, Allemand A, Da Silva LM, et al. Antiulcerogenic activity of hydroalcoholic extract of Achillea millefolium L.: involvement of the antioxidant system. J Ethnopharmacol. 2010;130(1):85-92.

17. Sidahmed HM, Hashim NM, Abdulla MA, et al. Antisecretory, gastroprotective, antioxidant and anti-Helicobacter pylori activity of zerumbone from Zingiber Zerumbet (L.) Smith. PLoS One. 2015;10:e0121060.

18. Salga MS, Ali HM, Abdulla MA, Abdelwahab SI. Gastroprotective activity and mechanism of novel dichlorido-zinc (II)-4-(2(5-methoxybenzylideneamino) ethyl) piperazin-1-iumphenolate complex on ethanol-induced gastric ulceration. Chem Biol Interact. 2012;195(2): 144-153.

19. Al-Amin M, Sultana GNN, Hossain CF. Antiulcer principle from Zingiber montanum. J Ethnopharmacol. 2012;141(1):57-60.

20. Vacca LL. Laboratory Manual of Histochemistry. New York, NY: Raven Press; 1985.

21. Luna LG. Manual of Histologic Staining Methods of the Armed Forces Institute of Pathology. 3rd ed. New York, NY: McGraw-Hill; 1968.

22. Collins TJ. ImageJ for microscopy. Biotechniques. 2007;43(1 Suppl): 25-30.

23. Kawahara Y, Nakase Y, Isomoto Y, et al. Role of macrophage colony stimulating factor (M-CSF)-dependent macrophages in gastric ulcer healing in mice. J Physiol Pharmacol. 2011;62(4):441. 
24. Demir S, Yilmaz M, Koseoglu M, Akalin N, Aslan D, Aydin A. Role of free radicals in peptic ulcer and gastritis. Turk J Gastroenterol. 2003; 14(1):39-43.

25. Albaayit SFA, Abba Y, Abdullah R, Abdullah N. Effect of Clausena excavata Burm. f (Rutaceae) leaf extract on wound healing and antioxidant activity in rats. Drug Des Devel Ther. 2015;9:3507-3518.

26. Mejia A, Kraft WK. Acid peptic diseases: pharmacological approach to treatment. Expert Rev Clin Pharmacol. 2009;2(3):295-314.

27. Santin JR, Lemos M, Júnior LCK, Niero R, de Andrade SF. Antiulcer effects of Achyrocline satureioides (Lam.) DC (Asteraceae)(Marcela), a folk medicine plant, in different experimental models. J Ethnopharmacol. 2010;130(2):334-339.

28. Gupta M, Mazumder UK, Manikandan L, Bhattacharya S, Senthilkumar GP, Suresh R. Anti-ulcer activity of ethanol extract of Terminaliapallida Brandis. in Swiss albino rats. J Ethnopharmacol. 2005;97(2):405-408.

29. Umamaheswari M, Asokkumar K, Rathidevi R, Sivashanmugam AT, Subhadradevi V, Ravi TK. Antiulcer and in vitro antioxidant activities of Jasminum grandiflorum L. J Ethnopharmacol. 2007;110(3):464-470.

30. Ishida K, Kojima R, Tsuboi M, Tsuda Y, Ito M. Effects of artichoke leaf extract on acute gastric mucosal injury in rats. Biol Pharm Bull. 2010;33(2):223-229.

31. Hiruma-Lima CA, Calvo TR, Rodrigues CM, Andrade FDP, Vilegas W, Brito ARMS. Antiulcerogenic activity of Alchornea castaneaefolia: effects on somatostatin, gastrin and prostaglandin. J Ethnopharmacol. 2006;104(1):215-224.

32. Tandon R, Khanna RD, Dorababu M, Goel RK. Oxidative stress and antioxidants status in peptic ulcer and gastric carcinoma. Indian J Physiol Pharmacol. 2004;48(1):115-118.

33. Alvarez-Suarez JM, Dekanski D, Ristic S, et al. Strawberry polyphenols attenuate ethanol-induced gastric lesions in rats by activation of antioxidant enzymes and attenuation of MDA increase. PLoS One. 2011;6(10):e25878

34. Kurose I, Higuchi H, Miura S, et al. Oxidative stress-mediated apoptosis of hepatocytes exposed to acute ethanol intoxication. Hepatology. 1997; 25(2):368-378.

35. Kwiecien S, Brzozowski T, Konturek SJ. Effects of reactive oxygen species action on gastric mucosa in various models of mucosal injury. J Physiol Pharmacol. 2002;53(1):39-50.

36. Da Silva LM, Allemand A, Mendes DAG, et al. Ethanolic extract of roots from Arctium lappa L. accelerates the healing of acetic acidinduced gastric ulcer in rats: Involvement of the antioxidant system. Food Chem Toxicol. 2013;51:179-187.

37. Shine V, Latha P, Shyamal S, et al. Gastric antisecretory and antiulcer activities of Cyclea peltata (Lam.) Hook. f. \& Thoms. in rats. J Ethnopharmacol. 2009;125(2):350-355.

38. Pihan G, Majzoubi D, Haudenschild C, Trier JS, Szabo S. Early microcirculatory stasis in acute gastric mucosal injury in the rat and prevention by 16, 16-dimethyl prostaglandin E2 or sodium thiosulfate. Gastroenterology. 1986;91(6):1415-1426.

39. Goel RK, Maiti RN, Manickam M, Ray AB. Antiulcer activity of naturally occurring pyrano-coumarin and isocoumarins and their effect on prostanoid synthesis using human colonic mucosa. Indian J Exp Biol. 1997; 35(10):1080-1083.

40. Rudin M, Thompson B. Apoptosis and disease: regulation and clinical relevance of programmed cell death. Annu Rev Med. 1997;48(1):267-281.
41. Konturek PC, Brzozowski T, Konturek SJ, et al. Apoptosis in gastric mucosa with stress-induced gastric ulcers. J Physiol Pharmacol. 1999; 50(2):211-225.

42. Cheng EH, Wei MC, Weiler S, et al. BCL-2, BCL-X L sequesters $\mathrm{BH} 3$ domain-only molecules preventing BAX-and BAK-mediated mitochondrial apoptosis. Mol Cell. 2001;8(3):705-711.

43. Chen SH, Liang YC, Chao JC, et al. Protective effects of Ginkgo biloba extract on the ethanol-induced gastric ulcer in rats. World J Gastroenterol. 2005;11(24):3746-3750.

44. Shichijo K, Ihara M, Matsuu M, Ito M, Okumura Y, Sekine I. Overexpression of heat shock protein 70 in stomach of stress-induced gastric ulcer-resistant rats. Dig Dis Sci. 2003;8(2):340-348.

45. Al Batran R, Al-Bayaty F, Abdulla MA, et al. Gastroprotective effects of Corchorus olitorius leaf extract against ethanol-induced gastric mucosal hemorrhagic lesions in rats. J Gastroenterol Hepatol. 2013;28(8): 1321-1329.

46. Al Batran R, Al-Bayaty F, Jamil Al-Obaidi MM, et al. In vivo antioxidant and antiulcer activity of Parkia speciose ethanolic leaf extract against ethanol-induced gastric ulcer in rats. PLoS One. 2013;8(5):e64751.

47. Dhiyaaldeen SM, Amin ZA, Darvish PH, et al. Protective effects of the chalcone 1-(4-hydroxy-phenyl)-3-m-tolyl-propenone against indomethacin-induced gastric erosive damage in rats. BMC Vet Res. 2014;10(1):961

48. Tanigawa T, Pai R, Arakawa T, Higuchi K, Tarnawski AS. TGF-beta signaling pathway: its role in gastrointestinal pathophysiology and modulation of ulcer healing. J Physiol Pharmacol. 2005;56(1):3-13.

49. Walsh MF, Ampasala DR, Hatfield J, et al. Transforming growth factor- $\beta$ stimulates intestinal epithelial focal adhesion kinase synthesis via Smad-and p38-dependent mechanisms. Am J Pathol. 2008;173(2): 385-399.

50. Antonisamy P, Duraipandiyan V, Aravinthan A, et al. Protective effects of friedelin isolated from Azima tetracantha Lam. against ethanolinduced gastric ulcer in rats and possible underlying mechanisms. Eur J Pharmacol. 2015;750:167-175.

51. Wei XM, Heywood GJ, DiGirolamo N, Thomas PS. Nicorandil inhibits the release of TNF-alpha from a lymphocyte cell line and peripheral blood lymphocytes. Int Immunopharmacol. 2003;3:1581-1588.

52. Martin GR, Wallace JL. Gastrointestinal inflammation: a central component of mucosal defense and repair. Exp Biol Med. 2006;231: 130-137.

53. Kishimoto $T$. Interleukin-6: from basic science to medicine -40 years in immunology. Annu Rev Immunol. 2005;23:1-21.

54. Mei X, Xu D, Xu S, Zheng Y, Xu S. Novel role of Zn (II)-curcuminin enhancing cell proliferation and adjusting pro inflammatory cytokinemediated oxidative damage of ethanol-induced acute gastric ulcers. Chem Biol Interact. 2012;197:1-39.

55. Sabat R, Grutz G, Warszawska K, et al. Biology of interleukin-10. Cytokine Growth Factor Rev. 2010;21:331-344.

56. Park SW, Oh TY, Kim YS, et al. Artemisiaasiatica extracts protect against ethanol-induced injury in gastric mucosa of rats. J Gastroenterol Hepatol. 2008;23:976-984.

57. Antonisamy P, Subash-Babu P, Alshatwi AA, et al. Gastroprotective effect of nymphayol isolated from Nymphaea stellata (Willd.) flowers: contribution of antioxidant, anti-inflammatory and anti-apoptotic activities. Chem Biol Interact. 2014;224:157-163.

\section{Dovepress}

\section{Publish your work in this journal}

Drug Design, Development and Therapy is an international, peerreviewed open-access journal that spans the spectrum of drug design and development through to clinical applications. Clinical outcomes, patient safety, and programs for the development and effective, safe, and sustained use of medicines are a feature of the journal, which

has also been accepted for indexing on PubMed Central. The manuscript management system is completely online and includes a very quick and fair peer-review system, which is all easy to use. Visit $\mathrm{http}: / /$ www.dovepress.com/testimonials.php to read real quotes from published authors. 